Clinical Research

\title{
Exercise in advanced prostate cancer elevates myokine levels and suppresses in-vitro cell growth
}

\author{
Jin-Soo Kim ${ }^{1,2}$, Dennis R. Taaffe (D) ${ }^{1,2}$, Daniel A. Galvão (DD ${ }^{1,2}$, Nicolas H. Hart ${ }^{1,2,3}$, Elin Gray ${ }^{2,4}$, Charles J. Ryan (DD ${ }^{5}$, Stacey A. Kenfield (iD ${ }^{6}$,
}

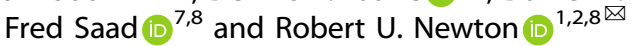

(c) The Author(s) 2022

BACKGROUND: Altering the systemic milieu through exercise has been proposed as a potential mechanism underlying exercisedriven tumour suppression. It is not yet known whether men with advanced prostate cancer can elicit such adaptations following a program of exercise. The purpose is to examine myokine levels of serum acquired from metastatic castrate-resistant prostate cancer (mCRPC) patients recruited to the INTERVAL-GAP4 trial before and after 6 months of exercise and its tumour-suppressive effect. METHODS: Twenty-five men with $\mathrm{mCRPC}$ (age $=74.7 \pm 7.1 \mathrm{yrs}$ ) were randomised to supervised multimodal (aerobic and resistance) exercise (EX) or self-directed exercise control group (CON). Body composition was assessed using dual-energy x-ray absorptiometry (DXA), and fasting blood in a rested state was collected at baseline and at 6 months. Serum levels of myokines (SPARC, OSM, decorin, IGF-1, and IGFBP-3) were measured. Serum was applied to the prostate cancer cell line DU145, and growth was assessed for $72 \mathrm{~h}$.

RESULTS: No significant change in body composition was observed. Adjusted serum OSM $(P=0.050)$ and relative OSM $(P=0.083)$, serum SPARC $(P=0.022)$ and relative SPARC $(P=0.025)$ increased in EX compared to CON. The area under curve (AUC) over $72 \mathrm{~h}$ showed a significant reduction in DU145 growth after applying post-intervention serum from the EX vs CON $(P=0.029)$.

CONCLUSION: Elevated myokine expressions and greater tumour-suppressive effects of serum after 6 months of periodised and autoregulated supervised exercise was observed in men with MCRPC. Exercise-induced systemic changes may slow disease progression in men with advanced prostate cancer.

Prostate Cancer and Prostatic Diseases (2022) 25:86-92; https://doi.org/10.1038/s41391-022-00504-x

\section{INTRODUCTION}

Exercise has been established as effective in improving physical function and supportive care outcomes for cancer patients, including those with advanced disease [1]. Furthermore, epidemiological studies of prostate cancer patients consistently report a positive association between increased physical activity levels and reduced risk of prostate cancer-specific mortality [2] and disease progression [3]. However, the causality of exercise-induced reduction of patient mortality and mechanisms of tumour suppression has not been thoroughly investigated in men with advanced prostate cancer $[4,5]$. Accordingly, a global multicentred Phase III randomised controlled exercise trial, INTERVALGAP4 [6], recruiting men with advanced prostate cancer is currently ongoing to examine the effect of exercise medicine on clinical outcomes, principally overall survival and disease progression, and the potential mechanisms by which exercise influences tumour biology.

Exercise induces multiple physiological changes, including alteration in cell-free and soluble molecules in the circulatory system known to have tumour-suppressive effects [5]. This has been further demonstrated in studies in which resting serum acquired after longterm exercise programs or exercise-conditioned serum obtained after a single bout of exercise applied to cancer cell lines produces substantial suppression of growth [7-13], with evidence supporting the involvement of exercise-induced serological insulin-like growth factor-1 (IGF-1) axis alteration in prostate cancer cell growth suppression [7, 11-13]. In our recent report [14], we showed suppression of androgen-independent prostate cancer cell line DU145 growth by applying serum acquired from patients with localised prostate cancer undergoing androgen deprivation therapy (ADT) following a 3-month exercise intervention and observed alterations in circulating cell-free/soluble factors compared to a pretrained state, suggesting a potential of exercise in prostate cancer suppression [5].

Skeletal muscle has been identified as an endocrine organ and elicits health-related benefits by producing cytokines termed myokines, especially during exercise [15]. Furthermore, in vivo and in vitro application of myokines, such as irisin [16-19], decorin

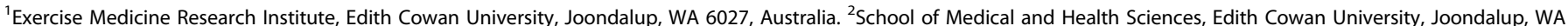

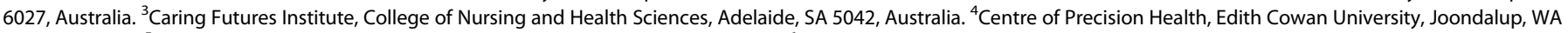

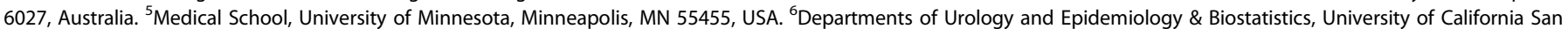

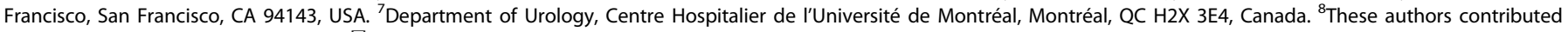
equally: Fred Saad, Robert U. Newton. ${ }^{\circledR}$ email: r.newton@ecu.edu.au

Received: 20 October 2021 Accepted: 20 January 2022

Published online: 12 February 2022 
[20-24], interleukin-6 (IL-6) [25, 26], interleukin-15 (IL-15) [27, 28], secreted protein acidic and rich in cysteine (SPARC) [29-32], and oncostatin M (OSM) [33-35], have reduced the growth and migration of various types of cancer cell lines, including prostate $[19,20,24-27,30]$. In addition, reduced myostatin expression counters the development of cachexia and may also contribute to tumour suppression by increasing irisin production [5]. However, despite the preclinical evidence, myokines are only considered as a potential molecular player for exercise-induced cancer suppression [5].

Although myokine expression in the non-cancer population is well documented [15], there has been no investigation of myokine expression and tumour-suppressive effects of exerciseconditioned serum in advanced prostate cancer patients who have undergone, and continue to receive, a range of cancer therapies inclusive of androgen blockade. Given the high disease load of these patients, with metastases and a shortened survival time, in addition to their castrate-resistant status underpinning an altered endocrine environment, it is important to determine if they can respond to exercise with the development of a more anti-tumour systemic milieu. Thus, in this study, we investigated resting serum myokine levels (irisin, decorin, IL-6, IL-15, SPARC, OSM, and myostatin) and growth hormone levels (IGF-1 and IGFBP-3) over the initial 6-month period of 2-year exercise intervention vs control group in metastatic castrate-resistant prostate cancer (mCRPC) patients. We also evaluated the potential exercise-induced tumour-suppressive effect by comparing serum acquired at baseline and after 6 months to the prostate cancer cell line DU145. We hypothesised that despite the heavy disease load and continuous treatment in this patient group (mCRPC), 6 months of supervised aerobic and resistance exercise would alter circulatory myokine levels and that exercise-conditioned serum obtained from the patients would reduce the growth of the prostate cancer cell line DU145.

\section{MATERIALS/SUBJECTS AND METHODS}

\section{Participants and exercise program}

Serum was collected from 25 men with $\operatorname{mCRPC}(E X, n=13$; CON, $n=12$ ) who were recruited for the INTERVAL-GAP4 trial (Clinical Trials Registry: NCT02730338) [6] from March 2016 to May 2020 at the Exercise Medicine Research Institute (EMRI; Edith Cowan University (ECU); WA, Australia) which was used for analysis (Fig. 1). The recruitment and randomisation of patients were undertaken as previously described [6]. Briefly, patients who had been identified as mCRPC (adenocarcinoma of the prostate with systemic metastatic disease despite castrate levels of testosterone $(<50 \mathrm{ng} / \mathrm{dl})$ due to orchiectomy or luteinising hormone-releasing hormone (LHRH) agonist, undergoing ADT (gonadotropin-releasing hormone $(\mathrm{GnRH})$ agonist/antagonist or prior bilateral orchiectomy)), and capable of performing exercise were recruited by clinician referrals.

Patients were randomly allocated to supervised exercise (EX) or a self-directed exercise control group (CON). The current study examines the initial 6 months of resistance and aerobic training completed thrice weekly as previously described [6], as the protocol for INTERVAL GAP4 initially commences with full supervision before transitioning to home-based exercise. Briefly, in the first and third exercise session of the week, structured resistance exercise (6 exercises, $2-5$ sets, 6-12 RM intensity adjusted using repetition maximum (RM)) with a combination of high-intensity interval training (HIIT) (aerobic exercise, $6 \times 60 \mathrm{~s}$, intensity adjusted to a rating of perceived exertion (RPE) of 8 on $0-10$ Borg scale) was prescribed, and 30-40 min of moderate-intensity continuous aerobic training (MICT) (cycling/walking) was undertaken at an intensity adjusted to RPE 6 in the second exercise session of the week. The exercise program was periodised and autoregulated across the week, month and 3-month cycles and autoregulated so

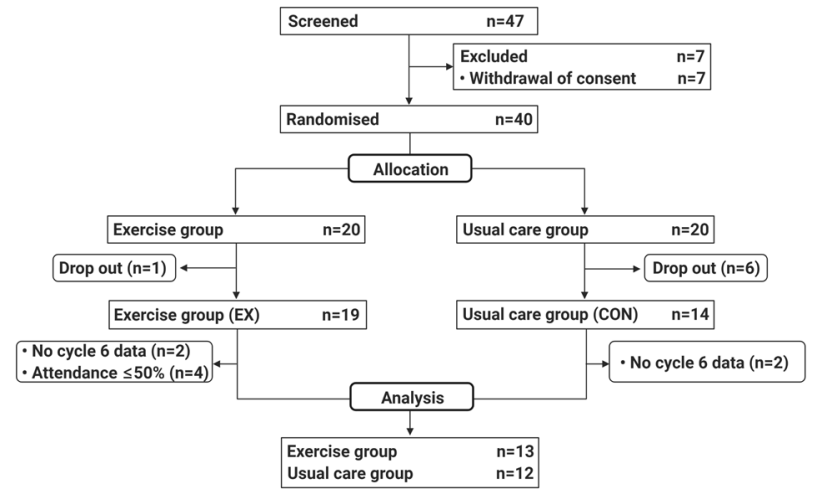

Fig. 1 Consort diagram. Cycle 6 indicates end of the initial 6-month phase of the INTERVAL GAP4 trial. Due to COVID-19 restrictions, patients who could not visit the centre for cycle 6 assessments were excluded from the analysis.

that intensity, volume and exercise selection was adjusted depending on the patient's readiness on the day. CON were provided with the American College of Sports Medicine (ACSM) guidelines for cancer survivors [36]. The study was funded by the Movember Foundation and ethically approved by the Human Research Ethics Committee at Edith Cowan University (ID: 13236 NEWTON). Written informed consent was obtained from all patients before inclusion.

\section{Body composition}

Body composition was assessed at baseline and after the initial 6 months of the study by Dual-energy X-ray Absorptiometry (DXA; Horizon A, Hologic, Washington, USA). Values derived were wholebody lean mass (LM, kg), upper-body LM (kg), lower-body LM (kg), whole-body fat mass (FM, kg), percent LM, percent FM, and LM index (total lean mass/height squared; $\mathrm{kg} / \mathrm{m}^{2}$ ). Body mass index (BMI) was calculated from weight divided by height squared $\left(\mathrm{kg} / \mathrm{m}^{2}\right)$.

\section{Blood assessment and analysis}

Resting blood samples were collected early in the morning for fasting specimens and at least $48 \mathrm{~h}$ post any exercise. The collected blood samples were processed to serum and stored at $-80^{\circ} \mathrm{C}$ until serum myokine analysis. Serum myokine levels for irisin, IL-6, IL-15, SPARC, OSM, and myostatin, were analysed using multiplex magnetic bead panels (HMYOMAG-56k-15 Huma, Millipore, Billerica, MA, USA), and serum decorin (ab99998, Decorin Human ELISA Kit, Abcam, Cambridge, United Kingdom), IGF-1 (ab211651, Human IGF-1 SimpleStep ELISA Kit, Abcam, Cambridge, United Kingdom), and IGFBP-3 (ab211652, Human IGFBP3 SimpleStep ELISA Kit, Abcam, Cambridge, United Kingdom) levels were analysed using appropriate enzyme-linked immunosorbent assay (ELISA) kits.

\section{Cell culture and real-time cellular analysis}

The human prostate cancer cell line, DU145 (ATCC HTB-81), was obtained from The Harry Perkins Institute for Medical Research, Nedlands, WA, Australia. Cells were cultured in RPMI-1640 media containing $10 \%$ fetal bovine serum (FBS), incubated at $37^{\circ} \mathrm{C}, 5 \%$ $\mathrm{CO} 2$, and routinely passaged at $\sim 80 \%$ confluence. Growth of DU145 cells was assessed using a Real-Time Cellular Analysis (RTCA) system, xCELLigence DP unit and E-plate (ACEA Bioscience, (A, USA) in the presence of human serum. Each well of E-plate was seeded with 15,000 DU145 cells with $100 \mu$ l of serum-free RPMI-1640. After $24 \mathrm{~h}$ of starvation, $100 \mu \mathrm{l}$ of growth media (RPMI1640) containing $20 \%$ human serum (final concentration of $10 \%$ ) was added to each well of the E-plate. The plates were incubated for $72 \mathrm{~h}$ while recording the Cell Index every hour. 


\section{Statistical analysis}

Based on Cell Index results from our previous research (Pre: $5.829 \pm 1.112$; Post: $4.566 \pm 1.515$ ) [14], 24 participants (12 each group) is required to achieve 0.80 power at an a level 0.05 twotailed. As a result, we obtained data and samples for 25 participants (CON, $n=12$; EX, $n=13$ ) from the INTERVAL GAP4 trial investigating the effect of exercise treatment on patients with mCRPC (Fig. 1). Data were analysed using $\mathrm{R}$ software (v4.0.2, The R Foundation), with the rstatix packages (v0.7.0, Kassambra, 2021) for statistics, ggplot2 packages (v3.3.3, Wickham, 2020) for visualisation and Desctools (v0.99.41, Slgnorell, 2021) for the area under the curve (AUC) calculations. Normality of the distribution for outcomes was tested using the Shapiro-Wilk test and Q-Q plot. Analysis of covariance (ANCOVA) was used to detect differences in post-intervention outcomes after 6 months for baseline value [37]. All values are presented as adjusted mean and $95 \%$ confidence interval. Tests were two-tailed and significance was set at $p<0.05$.

\section{RESULTS}

\section{Patient characteristics}

Patient characteristics are presented in Table 1. No significant difference between groups at baseline was evident in body weight, total $\mathrm{LM}$, percent $\mathrm{LM}, \mathrm{LM}$ index, $\mathrm{FM}$, percent $\mathrm{FM}$, BMI, serum levels of three myokines (OSM, SPARC, and decorin), and

Table 1. Baseline characteristics of exercise and usual care control group.

\begin{tabular}{|c|c|c|c|}
\hline & $\begin{array}{l}\text { CON }(n=12) \\
(\text { mean } \pm \text { SD })\end{array}$ & $\begin{array}{r}\mathrm{EX}(n=13) \\
(\mathrm{mean} \pm \mathrm{SD})\end{array}$ & $P$-value \\
\hline Age & $76.9 \pm 7.1$ & $72.6 \pm 7.0$ & 0.140 \\
\hline Height (m) & $1.7 \pm 0.1$ & $1.7 \pm 0.1$ & 0.608 \\
\hline Body weight (kg) & $82.1 \pm 13.4$ & $93.7 \pm 20.8$ & 0.164 \\
\hline Total lean mass (kg) & $49.1 \pm 8.2$ & $53.1 \pm 10.4$ & 0.364 \\
\hline $\begin{array}{l}\text { Percent lean } \\
\text { mass (\%) }\end{array}$ & $59.8 \pm 4.0$ & $57.0 \pm 3.9$ & 0.099 \\
\hline $\begin{array}{l}\text { Lean mass index } \\
\left(\mathrm{kg} / \mathrm{m}^{2}\right)\end{array}$ & $16.7 \pm 2.1$ & $17.6 \pm 1.9$ & 0.292 \\
\hline Total fat mass (kg) & $26.9 \pm 6.7$ & $33.4 \pm 10.5$ & 0.118 \\
\hline Percent fat mass (\%) & $34.4 \pm 4.7$ & $37.1 \pm 4.4$ & 0.143 \\
\hline $\begin{array}{l}\text { Presence of nodal } \\
\text { metastasis }\end{array}$ & 9 & 8 & - \\
\hline $\begin{array}{l}\text { Presence of bone } \\
\text { metastasis }\end{array}$ & 8 & 10 & - \\
\hline $\begin{array}{l}\text { Presence of nodal } \\
\text { and bone metastasis }\end{array}$ & 5 & 5 & - \\
\hline $\begin{array}{l}\text { ARTA (e.g., } \\
\text { abiraterone and } \\
\text { enzalutamide) naïve } \\
\text { patients }\end{array}$ & 8 & 7 & - \\
\hline Patients on ARTA & 4 & 6 & - \\
\hline BMI $\left(\mathrm{kg} / \mathrm{m}^{2}\right)$ & $28.0 \pm 4.0$ & $31.1 \pm 4.6$ & 0.149 \\
\hline IGF-1 (ng/ml) & $841.1 \pm 636.6$ & $806.5 \pm 547.0$ & 0.905 \\
\hline IGFBP-3 (ng/ml) & $13273.6 \pm 5871.5$ & $6987.9 \pm 2054.7$ & $<0.001$ \\
\hline Oncostatin M (ng/ml) & $6.6 \pm 4.9$ & $4.5 \pm 3.0$ & $0.503^{*}$ \\
\hline $\operatorname{SPARC}(\mathrm{pg} / \mathrm{ml})$ & $495.7 \pm 158.4$ & $408.1 \pm 82.1$ & $0.605^{*}$ \\
\hline Decorin (ng/ml) & $64.7 \pm 7.3$ & $63.0 \pm 10.6$ & 0.695 \\
\hline
\end{tabular}

Three patients from the CON and EX group each commenced chemotherapy (Docetaxel or Cabazitaxel) during the exercise period. ARTA Androgen receptor-targeted agents. *Indicates Wilcoxon-rank test used for statistical analysis otherwise independent $t$-test.
IGF-1, although serum levels of IGFBP-3 were significantly higher in CON. The average percentage of exercise sessions completed in EX was $82.5 \pm 13.0 \%$ out of a total of 72 sessions.

\section{Body composition}

Adjusted body weight, total LM, percent LM, LM index, FM, percent FM, and BMI adjusted for baseline did not show a significant difference between the EX and CON groups after the 6-month intervention (Table 2).

\section{Myokines and IGF-1/IGFBP-3}

A total of seven different myokines (irisin, decorin, IL-6, IL-15, SPARC, OSM, and myostatin), IGF-1, and IGFBP-3 were analysed from serum acquired at baseline and after the exercise intervention to examine the effect of exercise on serum levels of myokines and the IGF-1 axis. However, due to a low recovery rate of irisin, IL6 , IL-15, and myostatin in multiplexed magnetic bead-based immunoassay, only OSM, SPARC, decorin, IGF-1, and IGFBP-3 were able to be analysed (Table 2). After adjusting 6-monthintervention serum levels for baseline levels, no significant differences were observed in IGF-1, IGFBP-3 levels, or IGF-1/ IGFBP-3 ratio. However, there were significant differences between groups in serum levels of OSM $(P=0.050)$ and SPARC $(P=0.022)$ at post-intervention adjusted by baseline. Relative SPARC levels (serum SPARC levels/body weight) increased significantly in EX compared to $\operatorname{CON}(P=0.025)$, and there was a trend for an increase in relative OSM (serum OSM levels/body weight) $(P=0.083)$.

Subgroup analysis for ARTA (CON-ARTA naïve, $N=8$; CONARTA, $N=4$; EX-ARTA naïve, $N=7$; EX-ARTA, $N=6$ ) demonstrated a significant increase in adjusted serum OSM and SPARC levels for baseline in EX-ARTA naïve compared to the patients in CON-ARTA $(P<0.05$; Supplementary Table $1 \mathrm{~S})$. In addition, subgroup analysis by chemotherapy (CON-NO Chemo, $N=9$, CON-Chemo, $N=3$; EXNO Chemo, $N=10$, EX-Chemo, $N=3$ ), revealed baseline adjusted serum OSM and SPARC levels to be significantly higher in EX Chemo group compared to CON Chemo group $(P<0.05$; Supplementary Table $2 S$ ). Furthermore, baseline adjusted serum decorin levels were significantly higher in the EX-ARTA subgroup compared to EX-ARTA naïve subgroup $(P<0.05$; Supplementary Table 1S), however, significantly lower baseline adjusted decorin was observed in the EX-Chemo subgroup compared to CON-NO Chemo subgroup $(P<0.05$; Supplementary Table $2 \mathrm{~S}$ ).

\section{Prostate cancer cell line growth analysis}

Three-day cell growth kinetics are presented in Fig. 2A. Although adjusted Cell Index at $72 \mathrm{~h}$ after administrating 6-month serum from EX or CON groups did not show a difference, adjusted Cell Index at 12 to $61 \mathrm{~h}$ revealed a significant decrease in EX compared to CON at each time point. Therefore, the area under curve (AUC) was calculated from the $72 \mathrm{~h}$ Cell Index plot (Table 3, Fig. 2B, C). Total cell growth AUC (0-72 h) was significantly reduced with the presence of serum obtained after 6 months of an exercise intervention in EX compared to CON after adjusting for baseline AUC $(P=0.029)$. In addition, the adjusted 6-month timepoint intervention AUC at 0 to $<24 \mathrm{~h}, 24$ to $<48 \mathrm{~h}$ and 48 to $72 \mathrm{~h}$ periods exhibited a significant decrease in EX compared to CON $(P=0.016, P=0.006$, and $P=0.039$, respectively) (Table 3, Fig. $2 C$ ).

\section{DISCUSSION}

In this sub-study comprised from the INTERVAL-GAP4 randomised controlled trial [6], we examined chronic adaptations in potential muscle-induced candidates for tumour suppression in men with mCRPC undertaking 6 months of exercise training. We confirmed that the first 6 months of an exercise intervention vs control produced an increase in myokine expression, specifically OSM, SPARC, and body weight relative SPARC, as well as a 
Table 2. Adjusted physical outcomes and serum OSM, SPARC, decorin, IGF-1, and IGFBP-3 levels. All outcomes are for the initial 6-month phase adjusted for baseline.

\begin{tabular}{|c|c|c|c|c|c|}
\hline & \multicolumn{2}{|l|}{$\operatorname{CON}(n=12)$} & \multicolumn{2}{|l|}{ EX $(n=13)$} & \multirow[t]{2}{*}{$P$-value } \\
\hline & Adjusted mean & 95\% confidence interval & Adjusted mean & 95\% confidence interval & \\
\hline \multicolumn{6}{|l|}{ Physical Outcomes } \\
\hline Total lean mass $(\mathrm{kg})$ & 50.7 & {$[49.4,51.9]$} & 50.6 & {$[49.4,51.8]$} & 0.948 \\
\hline Percent lean mass (\%) & 57.7 & {$[56.4,59.0]$} & 58.4 & {$[57.1,59.6]$} & 0.454 \\
\hline Lean mass index $\left(\mathrm{kg} / \mathrm{m}^{2}\right)$ & 17.0 & {$[16.6,17.4]$} & 17.2 & {$[16.8,17.6]$} & 0.625 \\
\hline Percent Fat Mass (\%) & 36.7 & {$[35.1,38.2]$} & 35.9 & {$[34.4,37.5]$} & 0.513 \\
\hline $\mathrm{BMI}\left(\mathrm{kg} / \mathrm{m}^{2}\right)$ & 30.0 & {$[29.4,30.7]$} & 29.2 & {$[28.6,29.8]$} & 0.068 \\
\hline \multicolumn{6}{|c|}{ Serum IGF-1, IGFBP-3, and myokine levels } \\
\hline IGF-1 (ng/ml) & 924.85 & {$[687.47,1162.24]$} & 878.29 & {$[650.23,1106.36]$} & 0.772 \\
\hline IGFBP-3 (ng/ml) & 10186.76 & {$[8554.44,11819.08]$} & 7884.04 & {$[6329.68,9438.40]$} & 0.068 \\
\hline Decorin (ng/ml) & 67.08 & {$[62.92,71.23]$} & 63.75 & {$[59.76,67.74]$} & 0.246 \\
\hline Relative IGF-1 ( $\mathrm{ng} / \mathrm{m} / \mathrm{kg})$ & 11.25 & {$[8.31,14.19]$} & 10.17 & {$[7.34,12.98]$} & 0.586 \\
\hline Relative IGFBP-3 $(\mathrm{ng} / \mathrm{ml} / \mathrm{kg})$ & 120.40 & {$[101.35,139.45]$} & 97.71 & {$[79.57,115.84]$} & 0.120 \\
\hline Relative OSM (ng/ml/kg) & 0.06 & {$[0.03,0.09]$} & 0.10 & {$[0.07,0.13]$} & 0.083 \\
\hline Relative SPARC $(\mathrm{pg} / \mathrm{ml} / \mathrm{kg})$ & 4.85 & {$[4.32,5.37]$} & 5.73 & {$[5.22,6.23]$} & 0.025 \\
\hline Relative Decorin $(\mathrm{ng} / \mathrm{ml} / \mathrm{kg})$ & 0.78 & {$[0.74,0.83]$} & 0.77 & {$[0.73,0.82]$} & 0.770 \\
\hline
\end{tabular}

All 6-month outcomes are adjusted for the baseline value.

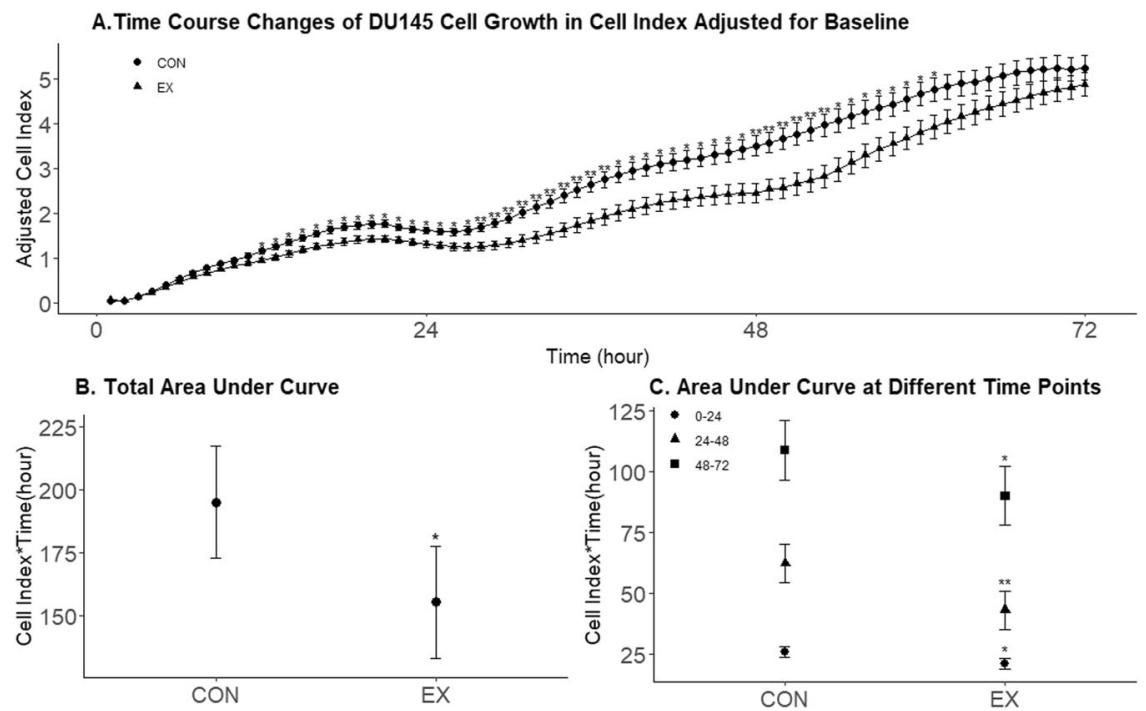

Fig. 2 Cell proliferation data. A Time-course changes of DU145 Cell growth in Cell Index adjusted for baseline values at each time point (adjusted mean \pm adjusted SE). The error bar indicates an adjusted SE. B Adjusted Area Under Curve (AUC) over $72 \mathrm{~h}$ incubation. C Adjusted Area Under Curve at different time points ( 0 to $<24 \mathrm{~h}, 24$ to $<48 \mathrm{~h}, 48$ to $72 \mathrm{~h}$ ). Due to contamination of a serum sample from one patient in the EX group, serum samples from only 12 patients in the CON group and 12 patients in the EX group were analysed. The grey bar indicates a $95 \%$ confidence interval of adjusted values. ${ }^{*} P<0.05,{ }^{* *} P<0.01$.

borderline increase in relative OSM. We also examined the effect of serum collected at baseline and 6 months on prostate cancer cell line DU145 growth. Although we cannot definitely conclude a direct relationship between exercise training elevated myokines and prostate cancer cell line growth, the 6-month serum drawn from the EX reduced DU145 cancer cell growth compared to CON.
While there are numerous hypotheses, the mechanistic details by which exercise influences tumour biology are unknown. In our prior review [5], we provide a rationale for the influence of muscleinduced myokines as anti-cancer agents acting through several pathways to drive apoptosis and suppress proliferation and metastasis. Furthermore, our team recently completed a singlegroup trial involving prostate cancer patients receiving ADT, and we 
Table 3. Area under curve from adjusted Cell Index adjusted for baseline.

\begin{tabular}{|c|c|c|c|c|c|}
\hline \multirow[t]{2}{*}{ Time frame (hour) } & \multicolumn{2}{|l|}{$\operatorname{CON}(n=12)$} & \multicolumn{2}{|l|}{ EX $(n=12)$} & \multirow[t]{2}{*}{$P$-value } \\
\hline & $\begin{array}{l}\text { Adjusted mean (Cell } \\
\text { Index*Time(h)) }\end{array}$ & $\begin{array}{l}95 \% \text { confidence } \\
\text { interval }\end{array}$ & $\begin{array}{l}\text { Adjusted mean (Cell } \\
\text { Index*Time(h)) }\end{array}$ & $\begin{array}{l}95 \% \text { confidence } \\
\text { interval }\end{array}$ & \\
\hline $0-72$ & 195.00 & {$[172.71,217.28]$} & 155.34 & {$[133.05,177.62]$} & 0.029 \\
\hline $0-24$ & 25.72 & {$[23.40,28.03]$} & 20.87 & {$[18.55,23.18]$} & 0.016 \\
\hline $24-48$ & 62.06 & {$[54.19,69.94]$} & 43.05 & {$[35.17,50.92]$} & 0.006 \\
\hline $48-72$ & 108.83 & {$[96.65,121.01]$} & 90.06 & {$[77.85,102.24]$} & 0.039 \\
\hline
\end{tabular}

The 6-month AUC outcomes are adjusted for baseline AUC. Due to contamination of a serum sample from one patient in the EX group, serum samples from only 12 patients in the CON group and 12 patients in the EX group were analysed.

demonstrated positive alterations in myokine concentrations with subsequent growth suppression of prostate cancer cell lines [14]. While this finding is intriguing, the question remained whether such anti-cancer effects of exercise could be induced in patients with more advanced prostate cancer. Patients with $\mathrm{MCRPC}$ have a very high disease load combined with accumulated treatment toxicities, resulting in considerable deconditioning, reduced muscle and bone mass and elevated fat mass. Should an anti-cancer systemic mechanism produced through exercise therapy be evident, then this could be a particularly attractive strategy for patients with mCRPC to slow disease progression.

The current study is the first to examine myokine expression before and at the 6-month exercise intervention in patients with $\mathrm{mCRPC}$ incorporating resistance and aerobic training. We focused on the endocrine function of skeletal muscle [15], given that preclinical studies demonstrated a positive role of myokines in cancer cell suppression [19, 20, 24-27, 30] and a retrospective study in prostate cancer patients showed a positive association between skeletal muscle mass and progression-free survival [38]. The results of serum myokine analysis in the current study showed significant elevation of serum SPARC and OSM levels in the EX group compared to the CON group, which is consistent with our previous report [14] in predominantly localised prostate cancer patients.

In addition, although this is speculative due to the limited sample number, our subgroup analysis for different treatments provided interesting observations regarding myokine expression. As androgen is a critical factor in muscle growth, we expected ARTA (androgen receptor-targeted agent), commonly prescribed as the first-line treatment for castrate-resistant prostate cancer, may have an impact on exercise-induced serum myokine levels. Interestingly, our subgroup analysis for ARTA and ARTA naïve showed a significant increase of serum OSM and SPARC in the EXARTA naïve subgroup compared to the CON-ARTA subgroup, suggesting that ARTA may impact exercise-induced OSM and SPARC levels possibly due to ARTA impacts on muscle size and physiology. Furthermore, our ARTA subgroup analysis demonstrated significantly increased serum decorin levels in the EX-ARTA group compared to EX-ARTA naïve; however, a decreased trend of decorin levels was observed in EX-Chemo compared to EX-NO Chemo, suggesting exercise-induced alteration of serum decorin may partially be impacted by chemotherapy. However, although these observations from our subgroup analysis are noteworthy, further research with larger patient numbers is required to fully elucidate these interactions.

Given that body composition, in terms of fat and muscle mass, influences cytokine levels in the blood $[39,40]$, it was somewhat surprising that we did not observe improvements in body composition. Although the intensity and volume prescribed to these patients were considerably high, a lack of differential response may be due to the disease and treatment load these patients are experiencing, compromising their ability to adapt with morphological changes. Similarly, a lack of change in body composition was also evident in our previous study involving prostate cancer patients with bone metastases following a 3-month exercise intervention [41]. The interference of aerobic exercise on adaptations to resistance training may also have occurred in these patients with $\mathrm{MCRPC}$, as we have reported previously for men with nonmetastatic prostate cancer being treated with ADT [42]. Whether or not this impacted the magnitude of increase in myokines and subsequent growth suppression in the cell line experiments cannot be determined.

We also observed a reduced prostate cancer cell line (DU145) growth after directly applying resting serum acquired following 6 months of exercise. For clinical relevance, we recruited patients under very strict criteria [6] and used the androgen-insensitive, metastatic prostate cancer cell line DU145 as this cell line originated from a 69-year-old Caucasian male with metastatic prostate cancer, which shares similar characteristics with mCRPC. Furthermore, it should be noted that resting serum was collected after at least $48 \mathrm{~h}$ of complete rest, and the acute physiological arousal from the last exercise session did not affect the results. Our previous report also observed reduced prostate cancer cell line growth by directly applying resting exercise-conditioned serum acquired from predominantly localised prostate cancer patients [14], suggesting exercise adaptation-induced systemic milieu alteration might positively influence tumour biology. Furthermore, previous studies by Barnard et al. [7], Leung et al. [11], and $\mathrm{Ngo}$ et al. [12] also reported reduced prostate cancer cell line (LNCaP) growth with the presence of resting serum obtained from active, healthy individuals and healthy persons following a shortterm period of exercise and dietary intervention. Although these reports demonstrated the potential role of exercise in inducing changes in the IGF-1 axis [7, 11, 12], serum IGF-1 and IGFBP-3 levels did not change in our cohort, suggesting that the serum myokine level changes due to exercise training are more likely candidate drivers suppressing DU-145 growth rather than the IGF1 axis. Nevertheless, consistent reduction of prostate cancer cell growth in previous studies and the current study provides important insight in the field of exercise oncology that not only should exercise be considered as a strategy to improve healthrelated outcomes for prostate cancer patients, but also as a potential daily-dosage strategy to create a tumour-suppressive environment.

The current study has a number of strengths and limitations worthy of comment. First, we used a randomised control trial design to investigate the expression of multiple myokines resulting from exercise. Second, DXA was used for body composition assessment providing accurate measures of fat and lean tissue. Third, by using RTCA, we were able to detect cell growth differences in multiple time points. This is important as previous studies that observed cell growth after applying human serum used end-point analysis and were unable to monitor cell growth kinetics. Fourth, the study provided clinically relevant 
evidence for tumour suppression using serum acquired from prostate cancer patients with $\mathrm{mCPRC}$ as prior to this data for myokine expression research has been limited to either healthy cohorts or those with metabolic disease, or patients with less advanced disease. However, as we used a multimodal exercise program, we cannot determine which exercise mode or if both contributed to the adaptation in myokine expression. Moreover, we analysed the data and samples available in our ongoing trial, INTERVAL-GAP4, which limits the volume of serum available for individual experiments and so this study was confined to investigate serum levels of myokines and prostate cancer cell growth. As there is limited research investigating myokine expression in patients with advanced prostate cancer, we made our initial sample size and power calculation based on available data from our previous trial in prostate cancer patients with localised disease [14]. Unfortunately, for the current study in patients with advanced disease our post-hoc analysis revealed that we only achieved statistical power of $65 \%$ in the adjusted AUC of Cell index, which likely reflects differences between the two patient groups in exercise responses. In addition, although we reported an increase in serum myokine levels and a significant reduction of DU145 cell growth after applying exerciseconditioned human serum, the current study is limited with regard to in-depth intercellular mechanistic measures to address the tumour-suppressive role of exercise-induced myokines or potential interaction between the treatments and myokines.

In conclusion, this study provides preliminary evidence for enhanced myokine expression, and a tumour-suppressive effect of serum collected from mCRPC patients after 6 months of vigorous, multimodal exercise. Future trials are needed to further elucidate the influence of exercise on myokine expression, particularly specifics of exercise prescription such as threshold exercise intensity, volume, and mode. Furthermore, more in-depth intercellular mechanistic research involving the application of both acute and chronically exercise-conditioned human serum is required to enhance our understanding of the direct tumour-suppressive role of myokines in patients with prostate cancer.

\section{DATA AVAILABILITY}

The data are available for bona fide researchers who request it from the authors.

\section{REFERENCES}

1. Jones LW, Alfano CM. Exercise-oncology research: past, present, and future. Acta Oncol. 2013;52:195-215.

2. Kenfield SA, Stampfer MJ, Giovannucci E, Chan JM. Physical activity and survival after prostate cancer diagnosis in the health professionals follow-up study. J Clin Oncol. 2011;29:726-32.

3. Richman EL, Kenfield SA, Stampfer MJ, Paciorek A, Carroll PR, Chan JM. Physical activity after diagnosis and risk of prostate cancer progression: data from the cancer of the prostate strategic urologic research endeavor. Cancer Res. 2011;71:3889-95.

4. Hart NH, Galvao DA, Newton RU. Exercise medicine for advanced prostate cancer. Curr Opin Support Palliat Care. 2017;11:247-57.

5. Kim J-S, Galvão DA, Newton RU, Gray E, Taaffe DR. Exercise-induced myokines and their effect on prostate cancer. Nat Rev Urol. 2021;18:519-42.

6. Newton RU, Kenfield SA, Hart NH, Chan JM, Courneya KS, Catto J, et al. Intense exercise for survival among men with metastatic castrate-resistant prostate cancer (INTERVAL-GAP4): a multicentre, randomised, controlled phase III study protocol. BMJ Open. 2018;8:e022899.

7. Barnard RJ, Ngo TH, Leung PS, Aronson WJ, Golding LA. A low-fat diet and/or strenuous exercise alters the IGF axis in vivo and reduces prostate tumor cell growth in vitro. Prostate. 2003;56:201-06.

8. Dethlefsen C, Hansen LS, Lillelund C, Andersen C, Gehl J, Christensen JF, et al. Exercise-induced catecholamines activate the hippo tumor suppressor pathway to reduce risks of breast cancer development. Cancer Res. 2017;77:4894-904.

9. Dethlefsen C, Lillelund C, Midtgaard J, Andersen C, Pedersen BK, Christensen JF, et al. Exercise regulates breast cancer cell viability: systemic training adaptations versus acute exercise responses. Breast Cancer Res Treat. 2016;159:469-79.
10. Devin JL, Hill MM, Mourtzakis M, Quadrilatero J, Jenkins DG, Skinner TL. Acute high intensity interval exercise reduces colon cancer cell growth. J Physiol. 2019;597:2177-84.

11. Leung PS, Aronson WJ, Ngo TH, Golding LA, Barnard RJ. Exercise alters the IGF axis in vivo and increases p53 protein in prostate tumor cells in vitro. J Appl Physiol (1985). 2004;96:450-4.

12. Ngo TH, Barnard RJ, Leung PS, Cohen P, Aronson WJ. Insulin-like growth factor I (IGF-I) and IGF binding protein-1 modulate prostate cancer cell growth and apoptosis: possible mediators for the effects of diet and exercise on cancer cell survival. Endocrinology. 2003;144:2319-24.

13. Rundqvist $H$, Augsten $M$, Stromberg $A$, Rullman $E$, Mijwel $S$, Kharaziha $P$, et al. Effect of acute exercise on prostate cancer cell growth. PLoS One. 2013;8:e67579.

14. Kim JS, Wilson RL, Taaffe DR, Galvao DA, Gray E, Newton RU. Myokine expression and tumor-suppressive effect of serum following 12 weeks of exercise in prostate cancer patients on ADT. Med Sci Sports Exerc. 2021;54:197-205.

15. Pedersen BK. The physiology of optimising health with a focus on exercise as medicine. Annu Rev Physiol. 2019;81:607-27.

16. Gannon NP, Vaughan RA, Garcia-Smith R, Bisoffi M, Trujillo KA. Effects of the exercise-inducible myokine irisin on malignant and non-malignant breast epithelial cell behavior in vitro. Int J Cancer. 2015;136:E197-202.

17. Liu J, Song N, Huang $Y$, Chen $Y$. Irisin inhibits pancreatic cancer cell growth via the AMPK-mTOR pathway. Sci Rep. 2018;8:15247.

18. Shao L, Li H, Chen J, Song H, Zhang Y, Wu F, et al. Irisin suppresses the migration, proliferation, and invasion of lung cancer cells via inhibition of epithelial-tomesenchymal transition. Biochem Biophys Res Commun. 2017;485:598-605.

19. Tekin S, Erden Y, Sandal S, Yilmaz B. Is irisin an anticarcinogenic peptide? Med-Sci. 2015;4:2172-80.

20. Hu Y, Sun H, Owens RT, Wu J, Chen YQ, Berquin IM, et al. Decorin suppresses prostate tumor growth through inhibition of epidermal growth factor and androgen receptor pathways. Neoplasia. 2009;11:1042-53.

21. Santra M, Eichstetter I, lozzo RV. An anti-oncogenic role for decorin. Downregulation of ErbB2 leads to growth suppression and cytodifferentiation of mammary carcinoma cells. J Biol Chem. 2000;275:35153-61.

22. Seidler DG, Goldoni S, Agnew C, Cardi C, Thakur ML, Owens RT, et al. Decorin protein core inhibits in vivo cancer growth and metabolism by hindering epidermal growth factor receptor function and triggering apoptosis via caspase-3 activation. J Biol Chem. 2006;281:26408-18.

23. Shi X, Liang W, Yang W, Xia R, Song Y. Decorin is responsible for progression of non-small-cell lung cancer by promoting cell proliferation and metastasis. Tumour Biol. 2015;36:3345-54.

24. Xu W, Neill T, Yang Y, Hu Z, Cleveland E, Wu Y, et al. The systemic delivery of an oncolytic adenovirus expressing decorin inhibits bone metastasis in a mouse model of human prostate cancer. Gene Ther. 2015;22:247-56.

25. Chung TD, Yu JJ, Spiotto MT, Bartkowski M, Simons JW. Characterisation of the role of IL-6 in the progression of prostate cancer. Prostate. 1999;38:199-207.

26. Lee SO, Chun JY, Nadiminty N, Lou W, Gao AC. Interleukin-6 undergoes transition from growth inhibitor associated with neuroendocrine differentiation to stimulator accompanied by androgen receptor activation during LNCaP prostate cancer cell progression. Prostate. 2007;67:764-73.

27. Morris JC, Ramlogan-Steel CA, Yu P, Black BA, Mannan P, Allison JP, et al. Vaccination with tumor cells expressing IL-15 and IL-15Ralpha inhibits murine breast and prostate cancer. Gene Ther. 2014;21:393-401.

28. Tang F, Zhao LT, Jiang Y, Ba de N, Cui LX, He W. Activity of recombinant human interleukin-15 against tumor recurrence and metastasis in mice. Cell Mol Immunol. 2008;5:189-96.

29. Aoi W, Naito Y, Takagi T, Tanimura Y, Takanami Y, Kawai Y, et al. A novel myokine, secreted protein acidic and rich in cysteine (SPARC), suppresses colon tumorigenesis via regular exercise. Gut. 2013;62:882-9.

30. Said N, Frierson HF Jr, Chernauskas D, Conaway M, Motamed K, Theodorescu D. The role of SPARC in the TRAMP model of prostate carcinogenesis and progression. Oncogene. 2009;28:3487-98.

31. Said N, Motamed K. Absence of host-secreted protein acidic and rich in cysteine (SPARC) augments peritoneal ovarian carcinomatosis. Am J Pathol. 2005;167: 1739-52.

32. Yiu GK, Chan WY, Ng SW, Chan PS, Cheung KK, Berkowitz RS, et al. SPARC (secreted protein acidic and rich in cysteine) induces apoptosis in ovarian cancer cells. Am J Pathol. 2001;159:609-22.

33. Hojman P, Dethlefsen C, Brandt C, Hansen J, Pedersen L, Pedersen BK. Exerciseinduced muscle-derived cytokines inhibit mammary cancer cell growth. Am J Physiol Endocrinol Metab. 2011;301:E504-10.

34. Hutt JA, DeWille JW. Oncostatin M induces growth arrest of mammary epithelium via a CCAAT/enhancer-binding protein delta-dependent pathway. Mol Cancer Ther. 2002;1:601-10.

35. Liu J, Spence MJ, Wallace PM, Forcier K, Hellstrom I, Vestal RE. Oncostatin $\mathrm{M}$-specific receptor mediates inhibition of breast cancer cell growth and 
down-regulation of the c-myc proto-oncogene. Cell Growth Differ. 1997;8:667-76.

36. Campbell KL, Winters-Stone KM, Wiskemann J, May AM, Schwartz AL, Courneya KS, et al. Exercise guidelines for cancer survivors: Consensus statement from international multidisciplinary roundtable. Med Sci Sports Exerc. 2019;51:2375-90.

37. Vickers AJ, Altman DG. Analysing controlled trials with baseline and follow up measurements. BMJ. 2001;323:1123-24.

38. Pak S, Kim MS, Park EY, Kim SH, Lee KH, Joung JY. Association of body composition with survival and treatment efficacy in castration-resistant prostate cancer. Front Oncol. 2020;10:558.

39. Kos K, Wong S, Tan B, Gummesson A, Jernas M, Franck N, et al. Regulation of the fibrosis and angiogenesis promoter SPARC/osteonectin in human adipose tissue by weight change, leptin, insulin, and glucose. Diabetes. 2009;58:1780-88.

40. Mai S, Grugni G, Mele C, Vietti R, Vigna L, Sartorio A, et al. Irisin levels in genetic and essential obesity: clues for a potential dual role. Sci Rep. 2020;10:1020

41. Galvao DA, Taaffe DR, Spry N, Cormie P, Joseph D, Chambers SK, et al. Exercise preserves physical function in prostate cancer patients with bone metastases. Med Sci Sports Exerc. 2018;50:393-9.

42. Newton RU, GalvÃO DA, Spry N, Joseph D, Chambers SK, Gardiner RA, et al. Exercise mode specificity for preserving spine and hip bone mineral density in prostate cancer patients. Med Sci Sports Exerc. 2019;51:607-14.

\section{ACKNOWLEDGEMENTS}

The authors thank Harry Perkins Institute, Nedlands, WA, Australia, for providing prostate cancer cell line DU145.

\section{AUTHOR CONTRIBUTIONS}

J-S Kim and RU Newton had full access to all the data in the study and take responsibility for the integrity of the data and accuracy of the data analysis. J-S Kim, RU Newton, DA Galvão, and DR Taaffe conceptualised the study. J-S Kim and RU Newton designed the study. RU Newton, NH Hart, and DA Galvão collected the clinical information, body composition and fasting blood samples. NH Hart and SA Kenfield supervised and directed the overall study's implementation, data collection, and data monitoring. J-S Kim analysed the data. J-S Kim and RU Newton were responsible for the drafting of the manuscript. RU Newton, NH Hart, DA Galvaõ, E Gray, SA Kenfield, and DR Taaffe provided administrative, technical, or material support. J-S Kim, RU Newton, NH Hart, DA Galvão, E Gray, CJ Ryan, SA Kenfield, F Saad, and DR Taaffe reviewed and edited the manuscript prior to submission.

\section{FUNDING}

This work was funded by the Movember Foundation. National Health and Medical Research Council Centre of Research Excellence (NHMRC-CRE; APP1116334) funded the additional materials involving serum analysis and cell work through Centre for Research Excellence in Prostate Cancer Survivorship. J-S.K is supported by the NHMRC
Centre for Research Excellence in Prostate Cancer Survivorship Scholarship. Open Access funding enabled and organized by CAUL and its Member Institutions.

\section{COMPETING INTERESTS}

The authors declare no competing interests.

\section{ETHICS APPROVAL}

The study was conducted according to the guidelines of the Declaration of Helsinki and approved by the Edith Cowan University Human Research Ethics Committee (ID: 13236 NEWTON).

\section{CONSENT TO PARTICIPATE}

Informed consent was obtained from all subjects involved in the study prior to inclusion.

\section{ADDITIONAL INFORMATION}

Supplementary information The online version contains supplementary material available at https://doi.org/10.1038/s41391-022-00504-x.

Correspondence and requests for materials should be addressed to Robert U. Newton.

Reprints and permission information is available at http://www.nature.com/ reprints

Publisher's note Springer Nature remains neutral with regard to jurisdictional claims in published maps and institutional affiliations.

\section{cc) (1)}

Open Access This article is licensed under a Creative Commons Attribution 4.0 International License, which permits use, sharing, adaptation, distribution and reproduction in any medium or format, as long as you give appropriate credit to the original author(s) and the source, provide a link to the Creative Commons license, and indicate if changes were made. The images or other third party material in this article are included in the article's Creative Commons license, unless indicated otherwise in a credit line to the material. If material is not included in the article's Creative Commons license and your intended use is not permitted by statutory regulation or exceeds the permitted use, you will need to obtain permission directly from the copyright holder. To view a copy of this license, visit http://creativecommons. org/licenses/by/4.0/.

(c) The Author(s) 2022 